\title{
New temperature and oxygen fugacity data of Martian nakhlite from Northwest Africa (NWA) 5790 and implications for shallow sulphur degassing
}

\author{
Zilong Wang ${ }^{1}$, Wei $\operatorname{Tian}^{1^{*}}$ (D) and Yankun Di ${ }^{2}$
}

\begin{abstract}
Newly analysed titanomagnetite-ilmenite (Tim-IIm) intergrowths from Martian nakhlite meteorite Northwest Africa (NWA) 5790 yielded crystallisation temperature up to $1032^{\circ} \mathrm{C}$ and oxygen fugacity $\left(f \mathrm{O}_{2}\right)$ up to $\triangle \mathrm{QFM}+1.6$, notably higher than previous estimates for nakhlite magmas (temperature $<950{ }^{\circ} \mathrm{C}, \mathrm{fO}_{2}=\triangle \mathrm{QFM}-0.5$ to $\triangle \mathrm{QFM}+1$ ). To interpret how the magma was reduced from $\triangle \mathrm{QFM}-0.5$ to $\triangle \mathrm{QFM}+1.6$, we used D-Compress to model the sulphur degassing process within a single thick lava pile. For $\mathrm{fO}_{2}$ to significantly decrease in this extended range, a sulphurrich (S content 4000-7000 ppm) Martian lava flow had to degas all the sulphur species at a certain final degassing pressure, which was 2-4 bar for NWA 988 and Lafayette and <0.7 bar for Y-000593 and Nakhla. These final degassing pressure data are in good agreement with the Martian nakhlite burial depth estimated by other petrological and geochemical methods. These estimates are also comparable with the excavation depth of $\sim 40 \mathrm{~m}$ based on the small (6.5 km in diameter) impact crater over the Elysium lava plain. The $\mathrm{fO}_{2}$-controlled sulphur degassing pressure may constitute a method for estimating the burial depth of sulphur-rich lava flows on Mars.
\end{abstract}

Keywords: Martian meteorites, Nakhlite, Fe-Ti oxides, Oxygen fugacity, Temperature

\section{Introduction}

Determining the oxygen fugacity $\left(\mathrm{fO}_{2}\right)$ of Martian shergottite-nakhlite-chassignite meteorites is important to understand the volcanic eruption process in ancient Mars. Both shergottite and chassignite have relatively reduced $f \mathrm{O}_{2}$, ranging from $\Delta \mathrm{QFM}-4\left(4 \log f \mathrm{O}_{2}\right.$ units below quartz-fayalite-magnetite buffer) to $\triangle \mathrm{QFM}-0.5$ (Hewins et al. 2020; Udry et al. 2020). However, $f \mathrm{O}_{2}$ in this range does not appear to represent magma erupted to the surface of Mars due to the high degree of crystallisation of shergottite and chassignite. Nakhlite has

\footnotetext{
*Correspondence: davidtian@pku.edu.cn

${ }^{1}$ The Key Laboratory of Orogenic Belts and Crustal Evolution, Ministry of Education, School of Earth and Space Sciences, Peking University, Beijing 100871, China

Full list of author information is available at the end of the article
}

a petrographic texture similar to terrestrial basalts, believed to have been excavated from lava piles buried at the shallow surface of Mars (Mikouchi et al. 2006, 2012; Shuster and Weiss 2005; Righter et al. 2008; Cohen et al. 2017). Therefore, the $f \mathrm{O}_{2}$ of nakhlite samples can directly provide constraints on lava flows erupted from ancient Martian volcanoes.

There is a considerable variation of $f \mathrm{O}_{2}$ measured from $\mathrm{Fe}-\mathrm{Ti}$ oxide phenocrysts in nakhlite samples, which ranges from $\triangle \mathrm{QFM}-0.5$ to $\triangle \mathrm{QFM}+1$ (Szymanski et al. 2010) for those ilmenite-titanomagnetite pairs that passing the $\mathrm{Mg} / \mathrm{Mn}$ equilibrium test of Bacon and Hirschmann (1988) (for details see Additional file 1: Figure $\mathrm{S} 1$ and Table S1). However, the full range of $f \mathrm{O}_{2}$ in nakhlites has not yet been fully resolved, as $\mathrm{Fe}-\mathrm{Ti}$ oxides studied likely represent only the relatively low-temperature history of these rocks. The closure temperature (Tc) 
corresponding to the highest observed $f \mathrm{O}_{2}$ is $<950{ }^{\circ} \mathrm{C}$, much lower than the crystallisation temperature of clinopyroxene phenocrysts in these melts $\left(1100{ }^{\circ} \mathrm{C}\right.$, Righter et al. 2008). Most studies applied geothermometers and oxybarometers to ilmenite-titanomagnetite pairs that occurred as veinlets and marginal growth along the cracks, which are considered to be late features (e.g., Szymanski et al. 2010; Treiman and Irving 2008), consistent with the low temperatures calculated. Ilmenite exsolution lamellae intergrowths have been reported in $\mathrm{Fe}-\mathrm{Ti}$ oxide phenocrysts, which may record higher temperature growth (e.g., Balta et al. 2017; Righter et al. 2014; Imae et al. 2005), but none of these intergrowths has been successfully analysed by electron probe microanalysis (EPMA) due to the inadequate thickness of the ilmenite lamellae.

Containing the highest mesostasis (glass phase) proportion, NWA 5790 is the nakhlite sample with the highest cooling rate (Corrigan and Velbel 2015; Mikouchi et al. 2012). Therefore, ilmenite-titanomagnetite pairs in NWA 5790 should record the highest closure temperature. We identified titanomagnetite-ilmenite intergrowths in $\mathrm{Fe}-\mathrm{Ti}$ oxide phenocrysts in nakhlite NWA 5790 , which were wide enough $(>2 \mu \mathrm{m})$ to locate a single EPMA spot. Then, we determined the equilibrium temperature and $f \mathrm{O}_{2}$ of these intergrowths. We conducted sulphur degassing modelling based on the newly obtained $f \mathrm{O}_{2}$ data and the extended variation range of $f \mathrm{O}_{2}$. The modelling results helped us constrain the degassing pressure during the crystallisation of $\mathrm{Fe}-\mathrm{Ti}$ oxide phenocrysts and the emplacement depth (i.e. burial depth) of different nakhlites.

\section{Methods \\ EPMA analysis}

Quantitative chemical analyses of minerals in the polished thin section NWA 5790 were conducted using a JEOL JXA-8230 electron microprobe analyzers (EMPA) equipped with four wavelength dispersive spectrometers at Key Laboratory of Orogenic Belts and Crustal Evolution of School of Earth and Space Sciences, Peking University. No field emission gun was used. The acceleration voltage and the beam current were $15 \mathrm{kV}$ and $10 \mathrm{nA}$, respectively. The beam diameter was set to "spot" mode (minimum size of the instrument). Counting time of $20 \mathrm{~s}$ was used for both peck and background. The SPI 53 minerals standard (U.S.) was utilised for the quantitative analysis: sanidine was employed for $\mathrm{K}$; diopside for $\mathrm{Ca}$ and $\mathrm{Mg}$; rutile for $\mathrm{Ti}$; jadeite for $\mathrm{Na}, \mathrm{Al}$ and $\mathrm{Si}$; chromium oxide for $\mathrm{Cr}$; rhodonite for $\mathrm{Mn}$; hematite for $\mathrm{Fe}$; and nickel silicide for $\mathrm{Ni}$. At the final calibration stage, the PRZ correction was performed. Detection limits of the oxides were 0.01 wt.\% for $\mathrm{K}_{2} \mathrm{O}, 0.02 \mathrm{wt} . \%$ for $\mathrm{Al}_{2} \mathrm{O}_{3}$ and
$\mathrm{Na}_{2} \mathrm{O}, 0.03$ wt.\% for $\mathrm{MgO}$ and $\mathrm{CaO}, 0.04$ wt.\% for $\mathrm{TiO}_{2}$, $\mathrm{Cr}_{2} \mathrm{O}_{3}, \mathrm{MnO}, \mathrm{FeO}$, and $\mathrm{NiO}$, and 0.06 wt.\% for $\mathrm{SiO}_{2}$.

Ilmenite-titanomagnetite geothermometer

The exchange equilibrium of $\mathrm{Fe}^{2+}+\mathrm{Ti}^{4+}$ for $2 \mathrm{Fe}^{3+}$ between ilmenite and titanomagnetite:

$$
\mathrm{Fe}_{2} \mathrm{TiO}_{4}^{\text {.Tim }}+\mathrm{Fe}_{2} \mathrm{O}_{3}^{\text {.Ilm }} \rightleftharpoons \mathrm{FeTiO}_{3}^{\text {Illm }}+\mathrm{Fe}_{3} \mathrm{O}_{4}^{\text {.Tim }}
$$

has been calibrated in several studies for use as a geothermometer (Andersen and Lindsley 1988; Ghiorso and Sack 1991; Powell and Powell 1977; Sauerzapf et al. 2008). Of these proposed geothermometer models, only the thermometer model of Sauerzapf et al. (2008) was experimentally calibrated at a temperature range $\left(800-1300{ }^{\circ} \mathrm{C}\right)$ that includes the temperature range $\left(900-1100{ }^{\circ} \mathrm{C}\right)$ recorded in $\mathrm{Fe}-\mathrm{Ti}$ oxides in NWA 5790. Thus, the geothermometer of Sauerzapf et al. (2008) was used in the temperature estimations in this study.

\section{Results}

\section{Petrography and P-T estimations}

The NWA 5790 sample in this study contains clinopyroxene $(55.7 \%)$, olivine $(6.1 \%)$, Fe-Ti oxides $(0.4 \%)$ and mesostasis (37.8\%) (Fig. 1a and Additional file 1: Figure S2). As shown in Fig. 1b, the Fe-Ti oxide grains are subhedral to anhedral, with a major axis of about $1 \mathrm{~mm}$ and a minor axis of about $0.5-1 \mathrm{~mm}$. There are two occurrence domains in the titanomagnetite-ilmenite intergrowths: (1) pervasively distributed exsolution textures characterised by thin ilmenite lamellae occurring in titanomagnetite; and (2) ilmenite veinlets and rim regions along the cracks of titanomagnetite host crystals. EPMA was used to analyse ilmenites from these two domains and their host titanomagnetites. Ilmenite veinlets and rim regions are typically different in composition from lamella, with high $\mathrm{TiO}_{2}, \mathrm{MgO}$, and $\mathrm{MnO}$ contents and low $\mathrm{Al}_{2} \mathrm{O}_{3}$, $\mathrm{Cr}_{2} \mathrm{O}_{3}$, and $\mathrm{FeO}$ contents (Table 1 ).

Titanomagnetite-ilmenite geothermometer and oxybarometer (Sauerzapf et al. 2008) were used to calculate the equilibrium temperature and $f \mathrm{O}_{2}$ of Tim-Ilm lamellae pairs, which are $1005-1032{ }^{\circ} \mathrm{C}$ and $\triangle Q F M+1.60$ to $\triangle \mathrm{QFM}+1.44$, respectively (Table 1 ). As shown in Fig. 2a, the equilibrium temperature and $f \mathrm{O}_{2}$ obtained in this study are remarkably higher than that calculated for Tim-Ilm pairs from other nakhlites, including Nakhla, Lafayette, Y-000593, and NWA 998 (Boctor et al. 1976; Bunch and Reid 1975; Sautter et al. 2002; Szymanski et al. 2010; Treiman and Irving 2008). The temperature of $1032{ }^{\circ} \mathrm{C}$ narrowed the gap between the crystallisation temperature of $\mathrm{Fe}-\mathrm{Ti}$ oxide phenocrysts and clinopyroxene phenocrysts, which is estimated to be $1100{ }^{\circ} \mathrm{C}$ (Righter et al. 2008). This suggests that the 


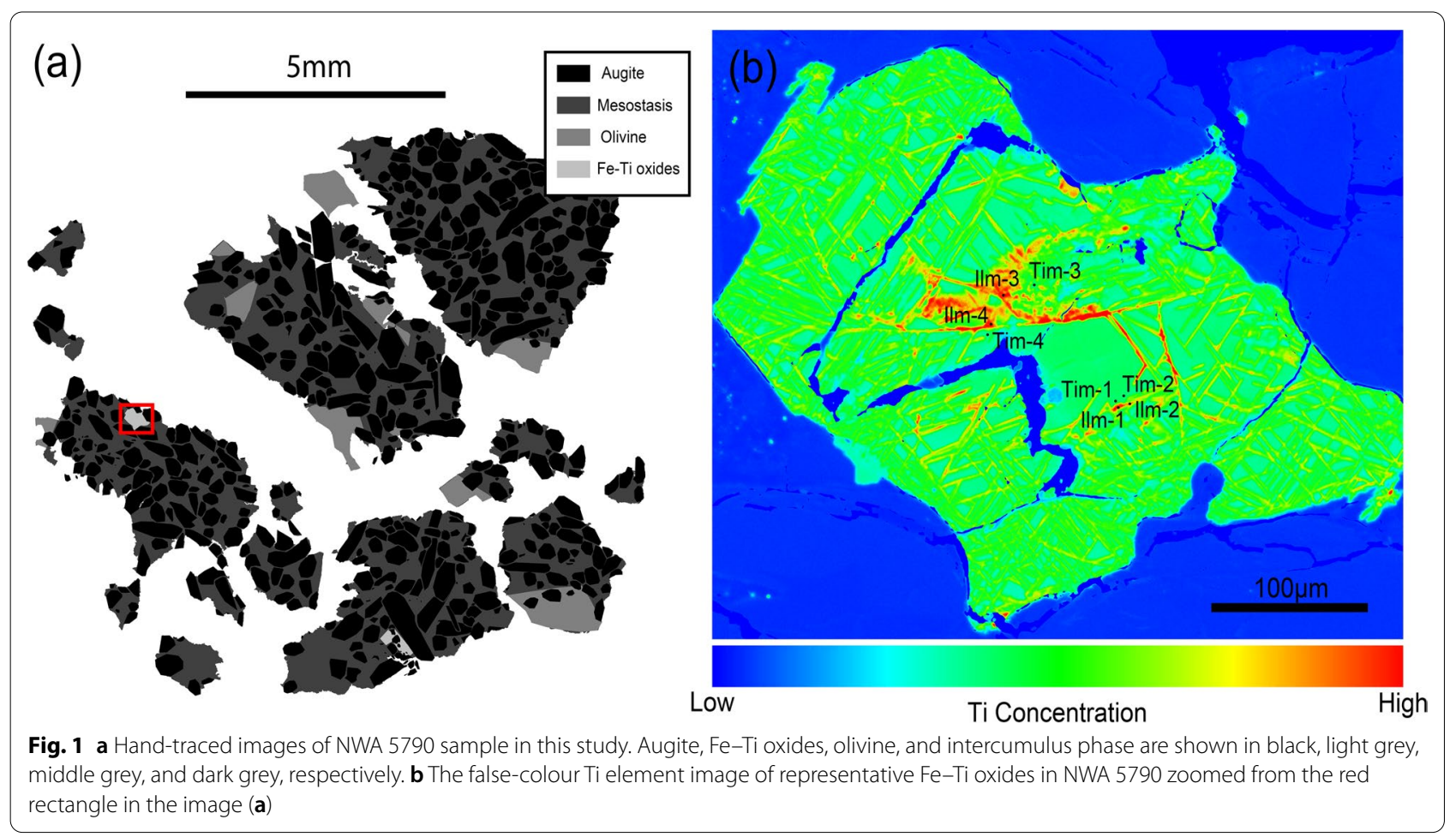

Table 1 Fe-Ti oxide compositions calculated based on stoichiometry

\begin{tabular}{|c|c|c|c|c|c|c|c|c|}
\hline No. & Tim1 & IIm1 & Tim2 & $11 \mathrm{~m} 2$ & Tim3 & $11 \mathrm{~m} 3$ & Tim4 & IIm4 \\
\hline Occurrence & Lamellae & & Lamellae & & Rim/veinlet & & Rim/veinlet & \\
\hline $\mathrm{SiO}_{2}$ & 0.20 & 0.21 & 0.23 & 0.31 & 0.08 & 0.25 & 0.09 & 1.46 \\
\hline $\mathrm{TiO}_{2}$ & 14.09 & 38.82 & 12.86 & 37.80 & 11.22 & 44.17 & 11.49 & 40.99 \\
\hline $\mathrm{Al}_{2} \mathrm{O}_{3}$ & 2.45 & 0.75 & 2.62 & 1.02 & 2.53 & 0.38 & 2.82 & 0.42 \\
\hline $\mathrm{Cr}_{2} \mathrm{O}_{3}$ & 2.48 & 1.15 & 2.28 & 1.49 & 2.25 & 0.68 & 2.15 & 0.66 \\
\hline $\mathrm{FeO}$ & 41.23 & 31.47 & 40.39 & 30.55 & 38.86 & 37.45 & 39.65 & 32.45 \\
\hline $\mathrm{Fe}_{2} \mathrm{O}_{3}$ & 33.35 & 24.26 & 36.15 & 25.79 & 39.15 & 14.79 & 39.09 & 18.44 \\
\hline $\mathrm{MgO}$ & 0.29 & 0.65 & 0.26 & 0.58 & 0.20 & 0.70 & 0.20 & 0.83 \\
\hline $\mathrm{MnO}$ & 0.44 & 0.73 & 0.40 & 0.81 & 0.47 & 0.92 & 0.29 & 1.58 \\
\hline $\mathrm{CaO}$ & 0.06 & 0.03 & 0.01 & 0.03 & n.d & 0.02 & n.d & 0.02 \\
\hline $\mathrm{V}_{2} \mathrm{O}_{3}$ & 0.50 & n.d & 0.50 & n.d & 0.50 & n.d & 0.50 & n.d \\
\hline $\mathrm{ZnO}$ & n.d & 0.10 & n.d & 0.10 & n.d & 0.10 & n.d & 0.10 \\
\hline Total & 95.09 & 98.20 & 95.70 & 98.48 & 95.26 & 97.95 & 96.28 & 97.15 \\
\hline $\mathrm{T}\left({ }^{\circ} \mathrm{C}\right)$ & 1032 & & 1005 & & 848 & & 901 & \\
\hline $\log \mathrm{fO}_{2}$ & -9.05 & & -9.30 & & -12.39 & & -11.15 & \\
\hline$\triangle \mathrm{QFM}^{\mathrm{a}}$ & +1.44 & & +1.60 & & +1.26 & & +1.49 & \\
\hline
\end{tabular}

n.d. not detected, Tim titanomagnetite, IIm ilmenite

${ }^{\text {a }}$ The $\triangle \mathrm{QFM}$ values were calculated using an equation from Frost (1991)

Fe-Ti oxide and clinopyroxene phenocrysts may share a similar crystallisation temperature $\left(>1032{ }^{\circ} \mathrm{C}\right)$ and $f \mathrm{O}_{2}$ $(\sim \Delta$ QFM +1.60$)$. As shown in Table 1 , the veinlet and rim ilmenites in the same sample yield an equilibrium temperature of $848-901{ }^{\circ} \mathrm{C}$ and $f \mathrm{O}_{2}$ of $\Delta \mathrm{QFM}+1.26$ to $\triangle \mathrm{QFM}+1.49$, which are consistent with previous studies (Fig. 2a). This comparison confirms that the high-Ti veinlets and rim regions grew at a later stage, in contrast to the ilmenite lamellae. 


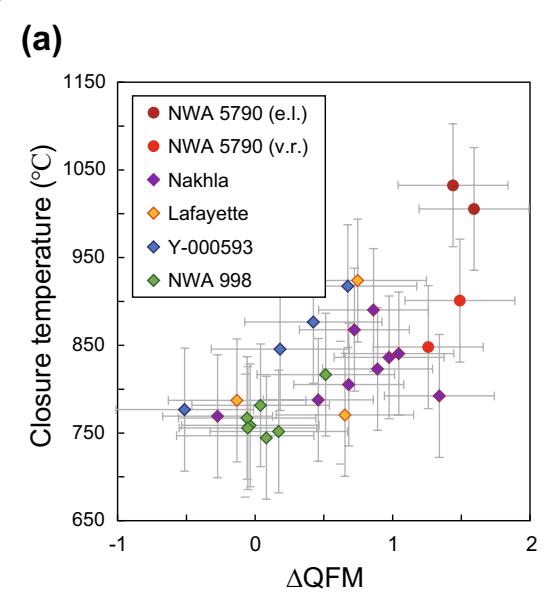

(b)

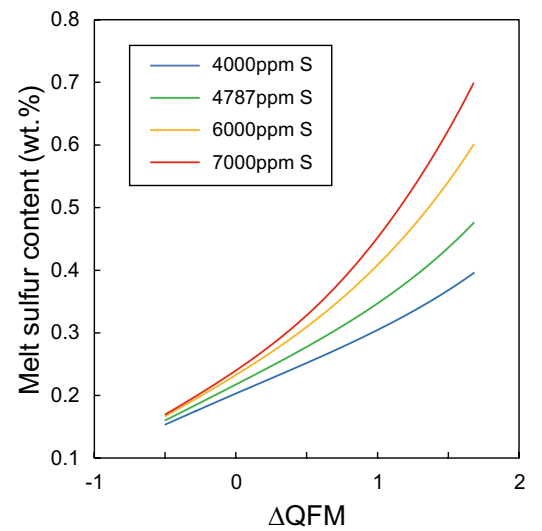

(c)

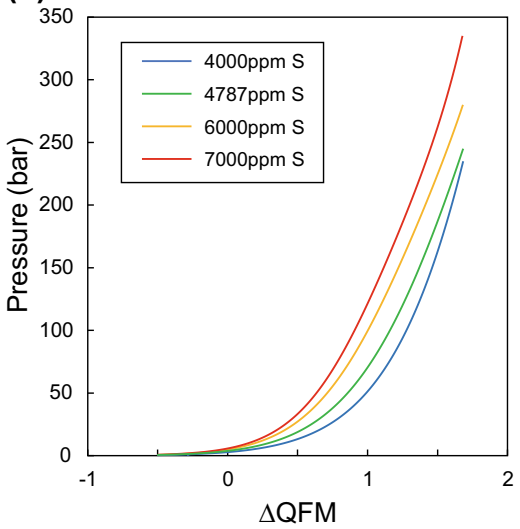

Fig. 2 a Closure temperature and $\mathrm{fO}_{2}$ (relative to QFM buffer) for NWA 5790 nakhlite titanomagnetite-ilmenite pairs in this study (red dots), compared to closure temperature and $\mathrm{fO}_{2}$ from titanomagnetite-ilmenite pairs in nakhlites from the literature (Boctor et al. 1976; Bunch and Reid 1975; Sautter et al. 2002; Szymanski et al. 2010; Treiman and Irving 2008). All closure temperatures and $\mathrm{fO}_{2}$ were recalculated using geothermometer and oxybarometer in Sauerzapf et al. (2008). Error bars for temperature and $\mathrm{fO}_{2}$ are $\pm 70^{\circ} \mathrm{C}$ and $\pm 0.5 \log \mathrm{fO}_{2}$ unit, respectively. b Total sulphur content vs. $\mathrm{fO}_{2}$ (expressed as $\triangle \mathrm{QFM}$ ) degassing simulations. c Pressure vs. $\mathrm{fO}_{2}$ (expressed as $\triangle \mathrm{QFM}$ ) degassing simulations. Degassing models calculated by D-Compress are in an open C-S-O-H system. For close-system degassing curves, see Additional file 1: Figure S3

\section{Sulphur degassing modelling}

During the evolution of silicate magma, any of several processes may change the $\mathrm{Fe}^{3+} / \Sigma \mathrm{Fe}$ ratios in the melt, reflecting the observed fluctuations in $\mathrm{fO}_{2}$ of nakhlite magma (Kress and Carmichael 1991). Firstly, the crystallisation of pyroxene and olivine increases the $\mathrm{Fe}^{3+} / \Sigma \mathrm{Fe}$ ratio in the residual melt (i.e. oxidises the melt; Brounce et al. 2017). Secondly, degassing of $\mathrm{H}_{2} \mathrm{O}$ and $\mathrm{CO}_{2}$ can oxidise the melt in open systems (e.g., Mathez (1984); Burgisser and Scaillet (2007); Humphreys et al. (2015)) or has no effect on melt $f \mathrm{O}_{2}$ in closed systems (e.g., Kelley and Cottrell (2012); Waters and Lange (2016)). These processes are unlikely in nakhlite magmas, which indicate reduction of the magma as crystallisation progresses.

Sulphur dissolves in silicate melts and takes the forms of sulphates $\left(\mathrm{S}^{6+}\right)$ or sulphides $\left(\mathrm{S}^{2-}\right)$, while sulphur is present as $\mathrm{SO}_{2}\left(\mathrm{~S}^{4+}\right)$ or $\mathrm{H}_{2} \mathrm{~S}\left(\mathrm{~S}^{2-}\right)$ in volcanic gas (Métrich et al. 2009). Therefore, sulphur degassing can lead to either oxidation or reduction of the residual melt phase, depending on the following reactions (Métrich et al. 2009):

$$
\mathrm{S}_{\text {(melt) }}^{2-}+3 \mathrm{Fe}^{3+}{ }_{2} \mathrm{O}_{3 \text { (melt) }}=\mathrm{SO}_{2 \text { (gas) }}+6 \mathrm{Fe}^{2+} \mathrm{O}_{\text {(melt) }}+\mathrm{O}_{\text {(melt) }}^{2--}
$$

and
(Gaillard and Scaillet, 2009). Thus, we modelled the effect of sulphur degassing on $f \mathrm{O}_{2}$ changes in nakhlite magma (Fig. $2 \mathrm{~b}$ and $\mathrm{c}$ ). The modelling was based on a progressive degassing model of the $\mathrm{C}-\mathrm{O}-\mathrm{H}-\mathrm{S}$ system using the software package D-Compress (Burgisser et al. 2015), which executes the gas-melt equilibrium model of Iacono-Marziano et al. (2012). Suppose that the system has some constraints (i.e. initial $\mathrm{H}_{2} \mathrm{O}$ and $\mathrm{CO}_{2}$ contents, magmatic $f \mathrm{O}_{2}$ ). In that case, based on the experimental calibration of the solubility of $\mathrm{H}_{2}, \mathrm{H}_{2} \mathrm{O}, \mathrm{CO}, \mathrm{CO}_{2}, \mathrm{SO}_{2}, \mathrm{H}_{2} \mathrm{~S}$, and $\mathrm{S}_{2}$ in the silicate melt and the calculation of homogeneous equilibria in the gas phase for the same species, D-Compress calculates the concentration and speciation of $\mathrm{C}, \mathrm{H}, \mathrm{O}$, and $\mathrm{S}$ in coexisting gas and silicate melt as a function of pressure and temperature (Brounce et al. 2017).

In this study, the nakhlite parent magma composition "NPM05" recently proposed by Sautter et al. (2012) was used. The initial $p \mathrm{CO}_{2}$ was $400 \mathrm{mbar}$ (Franz et al. 2019), the $\mathrm{H}_{2} \mathrm{O}$ content was 1.44 wt.\% (Weis et al. 2017), and the initial $f \mathrm{O}_{2}$ was $\Delta \mathrm{FMQ}+1.6$ at $1100{ }^{\circ} \mathrm{C}$. As D-Compress calculates the initial sulphur content of the melt based on implemented solubility laws (Longpré et al. 2017), and sulphur degassing is most sensitive to pressure variation (Gaillard and Scaillet 2009), the initial sulphur

$$
\mathrm{SO}_{4(\text { melt })}^{2-}+2 \mathrm{Fe}^{2+} \mathrm{O}_{(\text {melt })}=\mathrm{SO}_{2 \text { (gas) }}+\mathrm{Fe}^{3+}{ }_{2} \mathrm{O}_{3 \text { (melt) }}+\mathrm{O}_{(\text {melt })}^{2-}
$$

Martian basalts have a sulphur content in the range of 4000-7000 ppm, much more abundant than Earth content of the melt (4000-7000 ppm) was controlled by 
adjusting the pressure. Moreover, calculating the "sulphur content at sulfide saturation" (SCSS, O'Neill (2020)) of "NPM05" yielded $4787 \mathrm{ppm}$, which is in the range of 4000-7000 ppm. Thus, the initial melt sulphur contents used in this study were 4000 ppm, 4787 ppm, 6000 ppm, and $7000 \mathrm{ppm}$, corresponding to the pressures of $235 \mathrm{bar}$, 245 bar, 280 bar, and 335 bar, respectively.

The main results of degassing modelling are: (1) in all realistic open and closed sulphur degassing systems, a net decrease is observed in the melt $\mathrm{fO}_{2}$ upon decompression (Fig. 2c and Additional file 1: Figure S3c); (2) sulphur degassing is predicted to begin after sulphur reaches saturation, but more effective sulphur degassing is achieved only at low pressures $(<50$ bar) with a significant drop in $\mathrm{fO}_{2}$ (Fig. 2b); (3) with increasing initial melt sulphur content, the melt becomes more reduced for a given pressure, and open-system degassing tends to promote this process more efficiently (Fig. 2b and c); (4) the melt $f \mathrm{O}_{2}$ can decrease to $\Delta \mathrm{QFM}-0.5$ at $<1$ bar (Fig. 3), and the $f \mathrm{O}_{2}$ variation from $\triangle \mathrm{QFM}+1.6$ to $\triangle \mathrm{QFM}-0.5$ can cover all the $\mathrm{fO}_{2}$ data recorded in equilibrium titanomagnetite-ilmenite intergrowths from nakhlites (Fig. 1). These results are consistent with sulfur degassing controlling the range of observed $\mathrm{fO}_{2}$ values.

\section{Discussion}

\section{Link between temperature, oxygen fugacity and burial} depth

As shown in Fig. 2a, ilmenite-titanomagnetite pairs in different nakhlites recorded variable closure temperatures when the Fe-Ti oxides cooling. When the cooling rate $(\mathrm{d} T / \mathrm{d} t)$ is low, the closure temperature recorded by the ilmenite-titanomagnetite pairs is also low, due to longer subsolidus re-equilibration process (e.g., Morgado et al. 2019; Hou et al. 2020). As discussed in Hou et al. (2020), the cooling rate $(\mathrm{d} T / \mathrm{d} t)$ is proportional to $\mathrm{Tc}^{2} /$ $\exp (1 / \mathrm{Tc})$, i.e.

$$
(\mathrm{d} T / \mathrm{d} t) \propto \mathrm{Tc}^{2} / \mathrm{e}^{1 / \mathrm{Tc}} .
$$

When Tc is large, the denominator $\mathrm{e}^{(1 / \mathrm{Tc})}$ is approximately 1 , so $(\mathrm{d} T / \mathrm{d} t)$ is proportional to the square of Tc, i.e.

$$
(\mathrm{d} T / \mathrm{d} t) \propto \mathrm{Tc}^{2}
$$

In the half-space one-dimensional cooling model, Richter et al. (2016) has shown that the time scale $(t)$ of cooling in any part of a lava flow is proportional to the square of depth $(z)$, where $z$ is the distance to the heat transfer boundary (i.e. burial depth). Therefore, the cooling rate at any height $z$ would be proportional to the reciprocal of $z^{2}$, i.e.

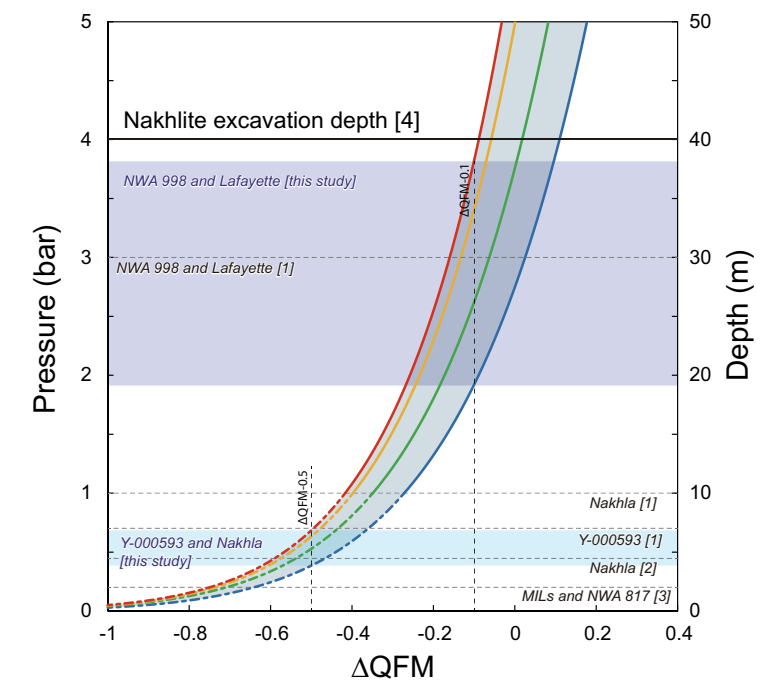

Fig. 3 Total sulphur content vs. $\mathrm{fO}_{2}$ (expressed as $\triangle \mathrm{QFM}$ ) degassing simulations at $0.04-5$ bar. Degassing models calculated with D-Compress are shown for an open $\mathrm{C}-\mathrm{S}-\mathrm{O}-\mathrm{H}$ system. For close-system degassing curves, see Additional file 1: Figure S4. At the pressure range below 1 bar (dashed-dotted line), the analytical continuation of the modelled curves was utilised to describe the relationship between pressure and $\mathrm{fO}_{2}$ based on the criterion $R^{2}=1$. The burial depths are cited from [1] Mikouchi et al. (2006); [2] Mikouchi and Miyamoto (2002); [3] Mikouchi et al. (2012). The nakhlite excavation depth is cited from [4] Cohen et al. (2017). In this study, the light blue regions are estimated to be the burial depth range of NWA 998 and Lafayette (ca. 30-40 m) and Y-000593 and $\operatorname{Nakhla}(<7 \mathrm{~m})$

$$
\mathrm{d} T / \mathrm{d} t \propto z^{-2}
$$

To sum up, we have a relationship between Tc and $z$ via the cooling rate $(\mathrm{d} T / \mathrm{d} t)$, which is:

$$
\text { Tc } \propto 1 / z \text {. }
$$

This means the relationship between $\mathrm{fO}_{2}$ and Tc in Fig. 2a is governed by the burial depth $(z)$. This relationship was built through the cooling rate $(\mathrm{d} T / \mathrm{d} t)$ of different nakhlites: the nakhlite from a deeper burial depth has a higher degassing pressure; it also has a lower cooling rate because of the thick overlying lava pile of nakhlites (e.g., Treiman 2005; Daly et al. 2019). Therefore, the minimum $\mathrm{fO}_{2}$ recorded in the $\mathrm{Fe}-\mathrm{Ti}$ oxides of nakhlite samples reflects its final burial depth.

\section{Implications on burial depth of nakhlite magma}

The nakhlites should have crystallised in an open system, which is supported by the parallel REE patterns of calculated melts (Udry and Day 2018) and the bimodal F/ $\mathrm{Cl}$ ratios of two generations of apatite (McCubbin et al. 
2013; Birski et al. 2019). Therefore, we can constrain the burial depth of a nakhlite by using its observed $f \mathrm{O}_{2}$ range and the open-system $f \mathrm{O}_{2}$-pressure relationships modelled by D-Compress. For a closed system, the results are shown in Additional file 1: Figure S3. The minimum $f \mathrm{O}_{2}$ recorded in the Lafayette and NWA 998 is $\triangle$ QFM -0.1 (Fig. 2a), which corresponds to the decompressing pressure range of 2-4 bar (deep blue region in Fig. 3). Likewise, the minimum $f \mathrm{O}_{2}$ recorded in the $\mathrm{Y}-000593$ and Nakhla is $\triangle$ QFM-0.5 (Fig. 2a), which corresponds to the decompressing pressure range of $<0.7$ bar (shallow blue region in Fig. 3). The results suggest that nakhlite NWA 998 and Lafayette crystallised at an emplacement depth (i.e. burial depth) of about 20-40 m, while Y-000593 and Nakhla crystallised at less than $7 \mathrm{~m}$ (Fig. 3).

These emplacement depth constraints are broadly consistent with burial depths reported in previous studies (Mikouchi et al. 2003, 2006, 2012). However, nakhlites are improbable to reside at a pressure of less than 0.04 bar $(0.4 \mathrm{~m})$, as 0.04 bar is the upper limit of the Martian atmospheric pressure (Ward 1974). Due to insufficient data, the burial depth of NWA 5790 cannot be constrained in this study. However, the pressure range of 235-335 bar obtained by D-Compress reflects the crystallisation depth of phenocrysts $(2.4-3.4 \mathrm{~km})$. Thus, a parental melt of nakhlite was formed and began to crystallise ilmenite lamellae in $\mathrm{Fe}-\mathrm{Ti}$ oxide phenocrysts at a depth of $>2.4-3.4 \mathrm{~km}$. The melt then ascended to a depth of $<40 \mathrm{~m}$ or erupted onto the surface, forming late-stage veinlets and rim ilmenites.

The consistency between the burial depth constrained by $\mathrm{fO}_{2}$ and the modelled sulphur degassing pressure, is consistent with the scenario that the nakhlites originated from the shallow levels of a thick lava flow or a staging lava pile at different depths, which was expressed as the single volcanic event model (e.g., Mikouchi et al. 2003; Treiman 2005; Day et al. 2006; Imae and Ikeda 2007; Udry et al. 2012; McCubbin et al. 2013; Righter et al. 2014; Jambon et al. 2016; Richter et al. 2016; Dottin et al. 2018). This occurrence is also consistent with the excavation depth of $\sim 40 \mathrm{~m}$ using the small impact crater (6.5 $\mathrm{km}$ in diameter) over the Elysium lava plain (Cohen et al. 2017), although their "discrete eruptive events model" is not consistent with the covariation between $f \mathrm{O}_{2}$ and burial depth.

\section{Error evaluation}

At all pressures, the solubility coefficients of volatile can lead to significant relative errors in degassing model (Iacovino et al. 2021). Relative errors induced by extreme solubility coefficients for estimating the gas molar ratio would raise from $\sim 30$ to $40-50 \%$ for basalt, when the pressure drops to $<100$ bar (Burgisser et al. 2015). This further raises a potential problem whether the D-Compress modelling can be extrapolated at lower pressure (i.e. a few bars) or not. If this problem does exist, the error bars would possibly be larger than the differences in predicted burial depths for different nakhlites. For example, errors of \pm 5 bars or more means that differences in burial depth between NWA 998/Lafayette ( 2-4 bars) and Y-000593/Nakhla ( 0.5 bars) would be the same within error. In this case, however, the relative differences between pressure is still sound mathematically. That is, the NWA 998/Lafayette and Y-000593/Nakhla samples were buried at similar, shallow depths and that the former were likely buried deeper than the latter. The fact that the burial depths reported here agree with previous studies suggest that the new values are something close to correct. In other words, it should be clear that the calculated pressure and depth are model-derived and the accuracy of these estimations is model-dependant. A better calibration would yield better model results. We noted that, in current stage, the estimations are semiquantitative rather than perfect quantitative.

\section{Concluding remarks}

Based on the newly analysed data of NWA 5790 and the modelling of sulphur degassing, the following conclusions can be reached:

(1) The titanomagnetite-ilmenite intergrowth in nakhlite NWA 5790 in this study extended the magma temperature record to $1032{ }^{\circ} \mathrm{C}$ and $f \mathrm{O}_{2}$ record to $\triangle \mathrm{QFM}+1.60$, respectively.

(2) The burial depths obtained from the $f \mathrm{O}_{2}$-controlled sulphur degassing pressure are consistent with the previously estimated burial depths of various nakhlites, about 20-40 m for NWA 998 and Lafayette and $<7 \mathrm{~m}$ for Y-000593 and Nakhla.

(3) Although the D-Compress model may be not calibrated sufficiently to resolve differences at low pressure of a few bars, our results suggest that analysis of $f \mathrm{O}_{2}$ coupled with modelling of sulphur degassing pressure may constitute a method for estimating the burial depth of sulphur-rich lava flows on Mars.

\section{Abbreviations}

$\mathrm{fO}_{2}$ : Oxygen fugacity; NWA: Northwest Africa. 


\section{Supplementary Information}

The online version contains supplementary material available at https://doi. org/10.1186/s40623-021-01492-3.

\section{Additional file 1: Figure S1. Equilibrium test plot (Bacon and} Hirschmann 1988) for ilmenite-titanomagnetite pairs reported in Table 4 of Szymanski et al. (2010) (blue dots) and lamellae ilmenites in this study (red dots). Error bars of data points are typical EPMA analytical uncertainty according to the compilation of Bacon and Hirschmann (1988). Table S1. Equilibrium test data. Figure S2. Contrast-enhanced BSE image of NWA 5790 thin-section. The diameter of the rounded mount is $1 \mathrm{~cm}$. Figure S3. (a) Closure temperature and $\mathrm{fO}_{2}$ (relative to QFM buffer) for NWA 5790 nakhlite titanomagnetite-ilmenite pairs in this study (red dots), compared to closure temperature and $\mathrm{fO}_{2}$ from titanomagnetite-ilmenite pairs in nakhlites from the literature (Boctor et al. 1976; Bunch and Reid 1975; Sautter et al. 2002; Szymanski et al. 2010; Treiman and Irving 2008). All closure temperatures and $\mathrm{fO}_{2}$ were recalculated using geothermometer and oxybarometer in Sauerzapf et al. (2008). Error bars for temperature and $\mathrm{fO}_{2}$ are $\pm 70{ }^{\circ} \mathrm{C}$ and $\pm 0.5 \log \mathrm{fO}_{2}$ unit, respectively. (b) Total sulphur content vs. $\mathrm{fO}_{2}$ (expressed as $\triangle \mathrm{QFM}$ ) degassing simulations. (c) Pressure vs. $\mathrm{fO}_{2}$ (expressed as $\triangle \mathrm{QFM}$ ) degassing simulations. Degassing models calculated by D-Compress are in close $\mathrm{C}-\mathrm{S}-\mathrm{O}-\mathrm{H}$ system. Figure $\mathbf{S 4}$. Total sulphur content vs. $\mathrm{fO}_{2}$ (expressed as $\triangle \mathrm{QFM}$ ) degassing simulations at 0.04-5 bar. Degassing models calculated with D-Compress are shown for a close $\mathrm{C}-\mathrm{S}-\mathrm{O}-\mathrm{H}$ system. At the pressure range below 1 bar, the analytical continuation of the modelled curves was utilised to describe the relationship between pressure and $\mathrm{fO}_{2}$ based on the criterion $\mathrm{R}^{2}=1$. The burial depths are cited from [1] Mikouchi et al. (2006); [2] Mikouchi and Miyamoto (2002); [3] Mikouchi et al. (2012). The nakhlite excavation depth is cited from [4] Cohen et al. (2017). In this study, the light blue regions are estimated to be the burial depth range of NWA 998 and Lafayette (ca. 30-40 $\mathrm{m})$ and $\mathrm{Y}-000593$ and Nakhla $(<7 \mathrm{~m})$.

\section{Acknowledgements}

Mingyue Gong is thanked for assisting on EPMA analyses. Haiping Ren is thanked for assisting on TIMA analyses.

\section{Authors' contributions}

ZW conducted the petrography and mineral chemistry analyses of the NWA 5790 meteorite. WT designed the experiment and make the explanation of the analysed data. ZW and WT co-wrote the manuscript. YD reviewed the manuscript and put forward constructive suggestions. The authors thank Enago (https://www.enago.cn) for their professional English language editing. All authors read and approved the final manuscript.

\section{Funding}

This research was financially supported by the National Natural Science Foundation of China (Grant Number 41630205).

\section{Availability of data and materials}

All data generated or analysed during this study are included in this published article.

\section{Declarations}

\section{Competing interests}

The authors declare that they have no conflict of interest.

\section{Author details}

${ }^{1}$ The Key Laboratory of Orogenic Belts and Crustal Evolution, Ministry of Education, School of Earth and Space Sciences, Peking University, Beijing 100871, China. ${ }^{2}$ Research School of Earth Sciences, Australian National University, Acton, ACT 2601, Australia.

Received: 17 April 2021 Accepted: 4 August 2021 Published online: 17 August 2021

\section{References}

Andersen DJ, Lindsley DH (1988) Internally consistent solution models for FeMg-Mn-Ti oxides; Fe-Ti. Oxides Am Miner 73(7-8):714-726

Bacon CR, Hirschmann MM (1988) Mg/Mn partitioning as a test for equilibrium between coexisting Fe-Ti oxides. Am Miner 73(1-2):57-61

Balta JB, Sanborn ME, Mayne RG, Wadhwa M, McSween HY, Crossley SD (2017) Northwest Africa 5790: a previously unsampled portion of the upper part of the nakhlite pile. Meteorit Planet Sci 52(1):36-59

Birski Ł, Słaby E, Chatzitheodoridis E, Wirth R, Majzner K, Kozub-Budzyń GA, Sláma J, Liszewska K, Kocjan I, Zagórska A (2019) Apatite from NWA 10153 and NWA 10645-the key to deciphering magmatic and fluid evolution history in nakhlites. Minerals 9(11):695

Boctor NZ, Meyer HOA, Kullerud G (1976) Lafayette meteorite: petrology and opaque mineralogy. Earth Planet Sci Lett 32(1):69-76. https://doi.org/10. 1016/0012-821X(76)90186-2

Brounce M, Stolper E, Eiler J (2017) Redox variations in Mauna Kea lavas, the oxygen fugacity of the Hawaiian plume, and the role of volcanic gases in Earth's oxygenation. Proc Natl Acad Sci USA 114(34):8997-9002

Bunch TE, Reid AM (1975) The nakhlites part I: petrography and mineral chemistry. Meteoritics 10(4):303-315

Burgisser A, Scaillet B (2007) Redox evolution of a degassing magma rising to the surface. Nature 445(7124):194-197

Burgisser A, Alletti M, Scaillet B (2015) Simulating the behavior of volatiles belonging to the $\mathrm{C}-\mathrm{O}-\mathrm{H}-\mathrm{S}$ system in silicate melts under magmatic conditions with the software D-compress. Comput Geosci 79:1-14

Cohen BE, Mark DF, Cassata WS, Lee MR, Tomkinson T, Smith CL (2017) Taking the pulse of Mars via dating of a plume-fed volcano. Nat Commun 8(1):640

Corrigan CM, Velbel MA (2015) Nakhlite Northwest Africa (NWA) 5790: discussions on cooling rate, oxidation state and lack of alteration. Paper presented the 46th Lunar and Planetary Science Conference (LPSC 2015). Houston, Texas, 16-20 Mar 2015

Daly L, Piazolo S, Lee MR, Griffin S, Chung P, Campanale F, Cohen BE, Hallis LJ, Trimby PW, Baumgartner R, Forman LV, Benedix GK (2019) Understanding the emplacement of Martian volcanic rocks using petrofabrics of the nakhlite meteorites. Earth Planet Sci Lett 520:220-230. https://doi.org/10. 1016/j.epsl.2019.05.050

Day JMD, Taylor LA, Floss C, Mcsween H (2006) Petrology and chemistry of MIL 03346 and its significance in understanding the petrogenesis of nakhlites on Mars. Meteorit Planet Sci 41(4):581-606

Dottin JW III, Labidi J, Farquhar J, Piccoli P, Liu MC, McKeegan KD (2018) Evidence for oxidation at the base of the nakhlite pile by reduction of sulfate salts at the time of lava emplacement. Geochim Cosmochim Acta 239:186-197

Franz HB, King PL, Gaillard F (2019) Sulphur on Mars from the atmosphere to the core. In: Filiberto J, Schwenzer SP (eds) Volatiles in the Martian crust, 1st edn. Elsevier, Amsterdam

Frost BR (1991) Introduction to oxygen fugacity and its petrologic importance oxide minerals. Rev Mineral Geochem 25(1):1-9

Gaillard F, Scaillet B (2009) The sulfur content of volcanic gases on Mars. Earth Planet Sci Lett 279(1-2):34-43. https://doi.org/10.1016/j.epsl.2008.12.028

Ghiorso MS, Sack O (1991) Fe-Ti oxide geothermometry: thermodynamic formulation and the estimation of intensive variables in silicic magmas. Contrib Mineral Petrol 108(4):485-510

Hewins RH, Humayun M, Barrat J-A, Zanda B, Lorand J-P, Pont S, Assayag N, Cartigny P, Yang S, Sautter V (2020) Northwest Africa 8694, a ferroan chassignite: bridging the gap between nakhlites and chassignites. Geochim Cosmochim Acta 282:201-226

Hou T, Botcharnikov R, Moulas E, Just T, Berndt J, Koepke J, Zhang ZC, Wang $M$, Yang ZP, Holtz F (2020) Kinetics of Fe-Ti oxide re-equilibration in magmatic systems: implications for thermo-oxybarometry. J Petrol. https:// doi.org/10.1093/petrology/egaa116

Humphreys MCS, Brooker RA, Fraser DG, Burgisser A, Mangan MT, McCammon C (2015) Coupled interactions between volatile activity and Fe oxidation state during arc crustal processes. J Petrol 56(4):795-814

lacono-Marziano G, Morizet Y, Le Trong E, Gaillard F (2012) New experimental data and semi-empirical parameterization of $\mathrm{H}_{2} \mathrm{O}-\mathrm{CO}_{2}$ solubility in mafic melts. Geochim Cosmochim Acta 97:1-23 
lacovino K, Matthews S, Wieser PE, Moore GM, Bégué F (2021) VESIcal Part I: an open-source thermodynamic model engine for mixed volatile $\left(\mathrm{H}_{2} \mathrm{O}-\mathrm{CO}_{2}\right)$ solubility in silicate melts. Earth Space Sci. https://doi.org/10.1029/2020E A001584

Imae N, Ikeda Y (2007) Petrology of the Miller Range 03346 nakhlite in comparison with the Yamato-000593 nakhlite. Meteorit Planet Sci 42(2):171-184

Imae N, Ikeda Y, Kojima H (2005) Petrology of the Yamato nakhlite. Meteorit Planet Sci 40(11):1581-1598

Jambon A, Sautter V, Barrat JA, Gattacceca J, Rochette P, Boudouma O, Badia D, Devouard B (2016) Northwest Africa 5790: revisiting nakhlite petrogenesis. Geochim Cosmochim Acta 190:191-212

Kelley KA, Cottrell E (2012) The influence of magmatic differentiation on the oxidation state of Fe in a basaltic arc magma. Earth Planet Sci Lett 329:109-121. https://doi.org/10.1016/J.EPSL.2012.02.010

Kress VC, Carmichael ISE (1991) The compressibility of silicate liquids containing $\mathrm{Fe}_{2} \mathrm{O}_{3}$ and the effect of composition, temperature, oxygen fugacity and pressure on their redox states. Contrib Mineral Petrol 108(1-2):82-92

Longpré MA, Stix J, Klügel A, Shimizu N (2017) Mantle to surface degassing of carbon- and sulphur-rich alkaline magma at El Hierro, Canary Islands. Earth Planet Sci Lett 460:268-280. https://doi.org/10.1016/j.epsl.2016.11. 043

Mathez EA (1984) Influence of degassing on oxidation-states of basaltic magmas. Nature 310(5976):371-375

McCubbin FM, Elardo SM, Shearer CK Jr, Smirnov A, Hauri E, Draper D (2013) A petrogenetic model for the comagmatic origin of chassignites and nakhlites: inferences from chlorine-rich minerals, petrology, and geochemistry. Meteorit Planet Sci 48(5):819-853

Métrich N, Berry AJ, O'Neill HSC, Susini J (2009) The oxidation state of sulfur in synthetic and natural glasses determined by X-ray absorption spectroscopy. Geochim Cosmochim Acta 73(8):2382-2399

Mikouchi T, Koizumi E, Monkawa A, Ueda Y, Miyamoto M (2003) Mineralogy and petrology of Yamato 000593: comparison with other Martian nakhlite meteorites. Antarct Meteor Res 16:34-57

Mikouchi T, Miyamoto M, Koizumi E, Makishima J, McKay G (2006) Relative burial depth of nakhlites: an updated. Paper presented at the 37rd Lunar and Planetary Science Conference. LPSC, Houston, Texas, 17-21 Mar 2006

Mikouchi T, Makishima J, Kurihara T, Hoffmann V H, Miyamoto M (2012) Relative burial depth of nakhlites revisited. Paper presented at the 43rd Lunar and Planetary Science Conference (LPSC 2012). Houston, Texas, 19-23 Mar 2012

Morgado E, Morgan DJ, Castruccio A, Ebmeier SK, Parada M, Brahm R, Harvey J, Gutiérrez F, Walshaw R (2019) Old magma and a new, intrusive trigger: using diffusion chronometry to understand the rapid-onset Calbuco eruption, April 2015 (southern Chile) Contrib. Mineral Petrol 174(7):1-11

O'Neill H (2020) The thermodynamic controls on sulfide saturation in silicate melts with application to ocean floor basalts. Earth Space Sci. https://doi. org/10.1002/essoar.10503096.1

Powell R, Powell M (1977) Geothermometry and oxygen barometry using coexisting iron-titanium oxides: a reappraisal. Mineral Mag 41(318):257-263

Richter F, Chaussidon M, Mendybaev R, Kite E (2016) Reassessing the cooling rate and geologic setting of Martian meteorites MIL 03346 and NWA 817. Geochim Cosmochim Acta 182:1-23
Righter K, Yang H, Costin G, Downs RT (2008) Oxygen fugacity in the Martian mantle controlled by carbon: new constraints from the nakhlite MIL 03346. Meteorit Planet Sci 43(10):1709-1723

Righter K, Keller LP, Rahman Z, Christoffersen R (2014) Redox-driven exsolution of iron-titanium oxides in magnetite in miller range (MIL) 03346 nakhlite: evidence for post crystallization oxidation in the nakhlite cumulate pile? Am Miner 99(11-12):2313-2319

Sauerzapf U, Lattard D, Burchard M, Engelmann R (2008) The titanomagnetiteilmenite equilibrium: new experimental data and thermo-oxybarometric application to the crystallization of basic to intermediate rocks. J Petrol 49(6):1161-1185

Sautter V, Barrat JA, Jambon A, Lorand JP, Gillet Ph, Javoy M, Joron JL, Lesourd M (2002) A new Martian meteorite from Morocco: the nakhlite North west Africa 817. Earth Planet Sci Lett 195(3-4):223-238. https://doi.org/ 10.1016/S0012-821X(01)00591-X

Sautter V, Toplis MJ, Lorand JP, Macri M (2012) Melt inclusions in augite from the nakhlite meteorites: a reassessment of nakhlite parental melt and implications for petrogenesis. Meteorit Planet Sci 47(3):330-344

Shuster DL, Weiss BP (2005) Martian surface paleotemperatures from thermochronology of meteorites. Science 309(5734):594-600

Szymanski A, Brenker FE, Palme H, El Goresy A (2010) High oxidation state during formation of Martian nakhlites. Meteorit Planet Sci 45(1):21-31

Treiman AH (2005) The nakhlite meteorites: augite-rich igneous rocks from Mars. Geochemistry 65(3):203-270

Treiman AH, Irving AJ (2008) Petrology of Martian meteorite Northwest Africa 998. Meteorit Planet Sci 43(5):829-854

Udry A, Day JMD (2018) 1.34 billion-year-old magmatism on Mars evaluated from the co-genetic nakhlite and chassignite meteorites. Geochim Cosmochim Acta 238:292-315

Udry A, McSween HY Jr, Lecumberri-Sanchez P, Bodnar R (2012) Paired nakhlites MIL 090030, 090032, 090136, and 03346: insights into the miller range parent meteorite. Meteorit Planet Sci 47(10):1575-1589

Udry A, Howarth GH, Herd CDK, Day JMD, Lapen TJ, Filiberto J (2020) What Martian meteorites reveal about the interior and surface of Mars. J Geophys Res Planets 125(12):1-34

Ward WR (1974) Climatic variations on Mars: 1. Astronomical theory of insolation. J Geophys Res 79(24):3375-3386

Waters LE, Lange RA (2016) No effect of $\mathrm{H}_{2} \mathrm{O}$ degassing on the oxidation state of magmatic liquids. Earth Planet Sci Lett 447:48-59. https://doi.org/10. 1016/j.epsl.2016.04.030

Weis FA, Bellucci JJ, Skogby H, Stalder R, Nemchin AA, Whitehouse MJ (2017) Water content in the Martian mantle: a Nakhla perspective. Geochim Cosmochim Acta 212:84-98

\section{Publisher's Note}

Springer Nature remains neutral with regard to jurisdictional claims in published maps and institutional affiliations.

\section{Submit your manuscript to a SpringerOpen ${ }^{\odot}$ journal and benefit from:}

- Convenient online submission

- Rigorous peer review

- Open access: articles freely available online

- High visibility within the field

- Retaining the copyright to your article

Submit your next manuscript at $\boldsymbol{\Delta}$ springeropen.com 